\title{
BIOCHAR AS SOIL CONDITIONER IN THE SUCCESSION OF UPLAND RICE AND COWPEA FERTILIZED WITH NITROGEN ${ }^{1}$
}

\author{
NEYTON DE OLIVEIRA MIRANDA ${ }^{2 *}$, ALEXANDRE SANTOS PIMENTA ${ }^{3}$, GUALTER GUENTHER COSTA DA \\ SILVA $^{3}$, ERMELINDA MARIA MOTA OLIVEIRA ${ }^{3}$, MARY ANNE BARBOSA DE CARVALHO ${ }^{4}$
}

\begin{abstract}
The effects of biochar and nitrogen application on yields of upland rice and cowpea and on soil fertility were determined in a greenhouse in Macaíba, RN, Brazil. The trial consisted of the succession of two crops in a completely randomized design and a factorial scheme, with four replicates. Initially, four doses of biochar and four doses of nitrogen were tested for cultivation of rice. Subsequently, four doses of biochar and two doses of nitrogen were tested in half of the pots maintained for planting cowpea. Soil was sampled after rice harvest for half of the pots and at end of the trial for the remaining pots. We evaluated the following parameters: mass of hundred grains of rice, dry shoot mass, panicle number, number of filled spikelets and of empty spikelets, and grain production. Determinations for cowpea were: pod number per pot, grain number per pod, and grain production per pot. Measured soil parameters were: $\mathrm{pH}$, contents of organic carbon, $\mathrm{P}, \mathrm{K}, \mathrm{Ca}$, $\mathrm{Mg}, \mathrm{Na}$, cation exchange capacity, and exchangeable sodium percentage. Biochar addition did not influence yield components of upland rice and cowpea, but resulted in increased soil $\mathrm{N}$ retention, which influenced rice dry shoot mass, spikelets sterility, panicle number, and grain mass. Biochar also promoted increased soil $\mathrm{pH}$, potassium content, and exchangeable sodium percentage and decreased calcium and magnesium concentrations.
\end{abstract}

Keywords: Oryza sativa. Vigna unguiculata. Charcoal. Carbon sequestration.

\section{CARVÃO VEGETAL COMO CONDICIONADOR DE SOLO NA SUCESSÃO ARROZ E FEIJÃO-CAUPI ADUBADOS COM NITROGÊNIO}

RESUMO - Os efeitos da aplicação de carvão vegetal e nitrogênio sobre a produtividade de arroz de terras altas e feijão-caupi e a fertilidade do solo foram determinados em ambiente protegido em Macaíba, RN, Brasil. O experimento constou de dois cultivos sucessivos em delineamento experimental completamente casualizado em arranjo fatorial, com quatro repetições. Inicialmente, foram testadas quatro doses de carvão vegetal e quatro de nitrogênio para a cultura do arroz. A seguir, foi cultivado feijão-caupi em metade dos vasos (quatro doses de carvão e duas de nitrogênio). O solo foi amostrado após a colheita do arroz, em metade dos vasos, e ao final do experimento, nos vasos restantes. Do arroz foram determinados, massa de cem grãos e, por vaso, massa seca da parte aérea, número de panículas, número de grãos cheios e grãos vazios e produção de grãos. Do feijão-caupi foram determinados: número de vagens por vaso, número de grãos por vagem e produção de grãos por vaso. No solo foram determinados: $\mathrm{pH}$, teores de carbono orgânico, $\mathrm{P}, \mathrm{K}, \mathrm{Ca}, \mathrm{Mg}$ e $\mathrm{Na}$, capacidade de troca de cátions e percentagem de sódio trocável. As doses de carvão vegetal não influenciaram nas características de produção do arroz e feijão-caupi, mas favoreceram a retenção de nitrogênio no solo, que se refletiu sobre massa seca da parte aérea do arroz, esterilidade das espiguetas, número de panículas e massa dos grãos. Além disso, promoveram aumento no $\mathrm{pH}$, teor de potássio e percentagem de sódio trocável do solo, com diminuição no teor de cálcio e magnésio.

Palavras-chave: Oryza sativa. Vigna unguiculata. Biochar. Sequestro de carbono.

\footnotetext{
*Corresponding author

${ }^{1}$ Received for publication in $11 / 08 / 2014$; accepted in 07/29/2016.

Paper extracted from the report of Senior Post Doctoral Research Grant received from CNPq.

${ }^{2}$ Department of Environmental and Technological Sciences, Universidade Federal Rural do Semi-Árido, Mossoró, RN, Brazil; neyton@ufersa.edu.br.

${ }^{3}$ Agricultural Sciences Specialized Unit, Universidade Federal do Rio Grande do Norte, Macaíba, RN, Brazil; alexandre_spimenta@hotmail.com,gualtermve@gmail.com, ermelindamota@yahoo.com.br.

${ }^{4}$ Graduate Program in Soil Science, Universidade Federal da Paraíba, Areia, PB, Brazil; eaamaryannecarvalho@hotmail.com.
} 


\section{INTRODUCTION}

According to the FAO (2011), the degradation of natural resources due to population pressure, climate change, and competition for land and water has social and cultural implications and affects biomass production, carbon accumulation, soil quality, water availability, biodiversity, and greenhouse gas emissions. In this context, dryland farming systems in semi-arid regions lead to water scarcity, salinization, pollution and sediment deposition in water reservoirs, degradation of the soil structure, reduction of soil fertility and carbon content, and nutrient depletion.

Population growth is accompanied by increased agricultural production, which should be accomplished in a sustainable way, using already existing crop areas and employing practices of soil and water conservation to increase carbon stocks via organic matter, thereby increasing water and nutrient retention erosion control and reducing greenhouse gas emissions.

High soil quality and productivity in terms of carbon storage can represent a trade-off between conservation targets and organic matter decomposition (JANZEN, 2006). This implies that, in order to accumulate $\mathrm{C}$ under fixed supplies of organic residues, it is necessary to inhibit biological activity and decomposition, which in turn negatively impacts soil fertility. One approach to solve this issue is to add large quantities of organic residues to the soil in order to achieve a balance between added and decomposed $\mathrm{C}$; alternatively, recalcitrant $\mathrm{C}$ forms might be added to the soil to stabilize carbon. Another approach is to use coal rich in pyrogenic carbon as agricultural soil conditioner (CARVALHO et al., 2013), because it resists decomposition and can remain in the soil for centuries (SOMBROEK et al., 2003).

Pyrolysis is the thermal decomposition of biomass in partial or total absence of oxygen and at temperatures between 400 and $800^{\circ} \mathrm{C}$. The raw material used can be any organic material, such as bark, wood, crop residues or other waste of agricultural or livestock origin (MAIA; MADARI; NOVOTNY, 2011; NÓBREGA, 2011; LINHARES et al., 2012).

Table 1. Chemical and physical soil characteristics.
In a comprehensive literature review about biochar addition to soils, Jeffery et al. (2011) reported variable results depending on the experimental conditions and soil properties. In terms of crop productivity, their analysis showed a small, but significant average increase of $10 \%$, with the best results observed in acid and neutral soils of sandy or loamy texture. This study indicates that the main mechanisms by which biochar increases productivity are soil acidity correction and increase of water retention and nutrient availability. However, application of biochar also present potential environmental risks due to toxic compounds, removal of plants residues that protect the soil, and the use of forests, conservation areas, or areas previously producing food for producing biomass for carbonization. Carbonization is acceptable for biomass that would be decomposed or burned or is obtained from residues of forest management, industry, and agriculture, besides the use of manure, organic garbage, and residues of pruning.

The objective of this work was to determine the effect of different doses of biochar and nitrogen on soil fertility in general and the yield of upland rice and cowpea in particular.

\section{MATERIAL AND METHODS}

The work was conducted from September 2013 to January 2014 in a greenhouse at the Specialized Unit of Agricultural Sciences, Federal University of Rio Grande do Norte, Macaíba, RN, Brazil (5'53' 11 "S and 35 21 ' 49" W). According to the Köppen classification, the climate is a transition between the types As' and BSh', with high temperatures throughout the year and rainfall in autumn and winter. Average annual temperature is $27.1^{\circ} \mathrm{C}$ and average air relative humidity $76 \%$.

Soil, classified as dystrophic Yellow Latosol (Typic Hapludox) according to the Brazilian System of soil Classification (SANTOS et al., 2013), was collected at a depth of 0 to $20 \mathrm{~cm}$, passed through a $2 \mathrm{~mm}$ mesh sieve and air-dried. Table 1 shows the main physical and chemical characteristics of the soil.

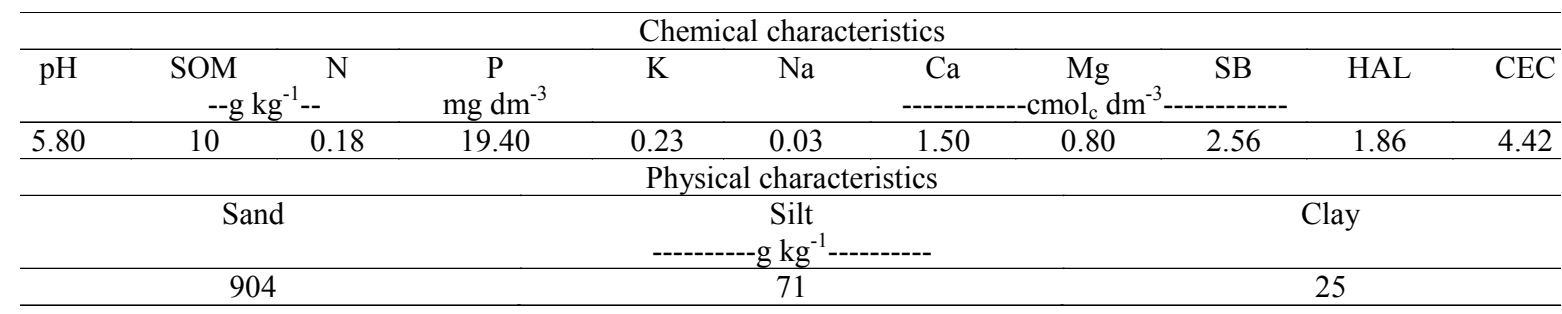

$\mathrm{SOM}=$ soil organic matter; $\mathrm{SB}=$ sum of bases; $\mathrm{HAL}=$ potential acidity $\mathrm{CEC}=$ cation exchange capacity. 
Biochar was produced from wood residues of cashew trees by the traditional "hot tail" kiln method, milled, and passed through a $2 \mathrm{~mm}$ sieve. Total moisture was $5.43 \%$ and chemical analysis showed $21 \%$ of volatile materials, $16 \%$ of ash, and $63 \%$ of fixed carbon. Nutrient levels were as follows: $\mathrm{N}=9.35 \mathrm{~g} \mathrm{~kg}^{-1} ; \mathrm{P}=89.16 \mathrm{mg} \mathrm{kg}^{-1} ; \mathrm{K}=1.34 \mathrm{~g} \mathrm{~kg}^{-1}$; $\mathrm{Cu}=10.21 \mathrm{mg} \mathrm{kg} \mathrm{kg}^{-1} ; \mathrm{Mn}=32.27 \mathrm{mg} \mathrm{kg} \mathrm{kg}^{-1}$; $\mathrm{Fe}=185.04 \mathrm{mg} \mathrm{kg}^{-1} ; \mathrm{Zn}=18.45 \mathrm{mg} \mathrm{kg}^{-1}$.

The experimental design was completely randomized in a factorial scheme, with four replicates. The first crop was upland rice (Oryza sativa L.) conducted as a $4 \times 4$ factorial scheme constituted by the factors biochar dose (D0 $=0 \mathrm{~kg} \mathrm{ha}^{-1}$; D1 $=3,500 \mathrm{~kg} \mathrm{ha}^{-1}$ or $15.75 \mathrm{~g}$ per pot; $\mathrm{D} 2=7,000 \mathrm{~kg} \mathrm{ha}^{-1}$ or $31.5 \mathrm{~g}$ per pot, and $\mathrm{D} 3=10,500 \mathrm{~kg} \mathrm{ha}^{-1}$ or $47.25 \mathrm{~g}$ per pot) and nitrogen $\left(\mathrm{N}\right.$, as calcium nitrate) $\left(0,30,60\right.$, and $\left.90 \mathrm{~kg} \mathrm{ha}^{-1}\right)$. After harvest, 32 pots were maintained for growing cowpea (Vigna unguiculata (L.) Walp.) under the residual effects of all doses of biochar and only the doses 0 and $90 \mathrm{~kg} \mathrm{ha}^{-1}$ of $\mathrm{N}$.

Mixtures of biochar and soil were placed in polyethylene pots with a capacity of $10 \mathrm{~L}$ and filled to a height of $20 \mathrm{~cm}$ from the bottom, resulting in a volume of 8 liters and a final mass of $11 \mathrm{~kg}$, with a density of $1.375 \mathrm{~kg} \mathrm{~cm}^{-3}$ before mixtures. Soil was weighted using a $20 \mathrm{~kg}$ scale with accuracy of $5 \mathrm{~g}$ and the weighing of biochar and fertilizer was performed in an electronic analytical scale with accuracy of $0.001 \mathrm{~g}$.

Upland rice cv. BRS Sertaneja was sowed along with the application of a single dose of the amount of nitrogen corresponding to each treatment, without any other fertilizer. After thinning, 14 days after sowing (DAS), three plants were left per pot. The crop was irrigated manually every three days and the amount of water was determined by difference after the weighing of four control pots, with $324 \mathrm{~mm}$ of water applied up to 120 DAS.

Rice was harvested 120 days after sowing. The plants were cut low to the ground and the panicles were separated to determine number per pot, number of filled and empty grains per pot, production per pot, and mass of 100 grains, both corrected to $13 \%$ moisture. Subsequently, the plants were dried in a forced air circulation oven at $65^{\circ} \mathrm{C}$ for 72 hours to determine dry mass of shoots per pot.

In terms of cowpea, we used the variety Itaim. After thinning at $10 \mathrm{DAS}$, three plants remained per pot. Irrigation was performed as described above, with $245 \mathrm{~mm}$ water applied until 59 DAS. In addition, there were two applications of $2.5 \%$ deltamethrin at a dose of $1 \mathrm{~mL}$ per liter of water for controlling Aphis spp. and Liriomyza sativae. The dry pods were harvested between 57 and 72 days after sowing for determination of number of pods per pot, number of grains per pod, and grain production per pot, corrected to $13 \%$ moisture.

Soil was sampled after harvest of rice (150 days after application of the treatments) in the pots that received the doses of 30 and $60 \mathrm{~kg} \mathrm{ha}^{-1}$ of $\mathrm{N}$ and after harvest of cowpea (220 days after application of the treatments) in the remaining pots. We measured soil $\mathrm{pH}$, soil organic carbon content, and contents of $\mathrm{P}, \mathrm{K}, \mathrm{Ca}, \mathrm{Mg}$ and $\mathrm{Na}$, having calculated CEC (cation exchange capacity) and ESP (exchangeable sodium percentage). Soil analyses were performed as described in EMBRAPA (2009).

Data from upland rice cultivation were submitted to variance analysis of the effects of the factors biochar and $\mathrm{N}$ and their interactions (coal $\mathrm{x}$ nitrogen), with regression analysis of significant effects. Data from cowpea cultivation were submitted to variance analysis of the effects of doses of biochar, two doses of $\mathrm{N}$, and their interaction, with regression analysis for the effects of doses of biochar and test of means (Duncan-p < 0.05) between the two doses of N. Data from soil analyses (including two sampling dates) were submitted to joint variance analysis to evaluate the effect of sampling and dose of biochar, followed by test of means and regression analysis. For each sampling, the effects of dose of biochar, two doses of N, and their interactions were analyzed, with regression analysis for doses of biochar and test of means between doses of $\mathrm{N}$.

\section{RESULTS AND DISCUSSION}

\section{Upland Rice Production Variables}

Different biochar doses had no significant effect on upland rice production variables. This result was also obtained by Carvalho et al. (2013), who stated the hypothesis that soil without application of biochar did not present limitations of availability of water, $\mathrm{K}$, or $\mathrm{P}$, and that the crop is tolerant to soil acidity. However, there was a significant effect of the $\mathrm{N}$ doses on number of filled grains per pot $(\mathrm{NFG}-\mathrm{p}<0.01)$ and rice production per pot (PRODR $-\mathrm{p}<0.01)$.

Apart from the effects of $\mathrm{N}$ doses, dry shoot mass (DSM - p < 0.05), number of panicles per pot (NP - p < 0.05), and number of empty grains per pot $(\mathrm{NEG}-\mathrm{p}<0.01)$ were significantly affected by interactions between doses of biochar and $\mathrm{N}$, while the mass of 100 grains (MHG $-\mathrm{p}<0.05$ ) was only significantly affected by the interaction. The effect of the interaction between biochar application and nitrogen addition on the yield components was one of the focuses of the research of Jeffery et al. (2011). Due to the high nitrogen requirements of rice, the possibility of deficiency makes nitrogen fertilizers key inputs for increasing rice productivity, although excessive application can cause increased costs, environmental pollution, and decreased rice quality (YOSHIDA, 1981; BUZETTI et al., 2006; YOSEFTABAR, 2013). 
We observed a linear increase in NFG and PRODR with increased $\mathrm{N}$ doses (Figure 1). Hereby, NFG increased by $20 \%$ when the quantity of $\mathrm{N}$ was increased from 0 to $30 \mathrm{~kg} \mathrm{ha}^{-1}$, by $35 \%$ when the dose was increased from 0 to $60 \mathrm{~kg} \mathrm{~N} \mathrm{ha}^{-1}$, and by $40 \%$ when the dose of $\mathrm{N}$ was increased from 0 to $90 \mathrm{~kg} \mathrm{ha}^{-1}$. The same increments in the doses of $\mathrm{N}$ caused increases in PRODR of 15, 26, and 29\%,

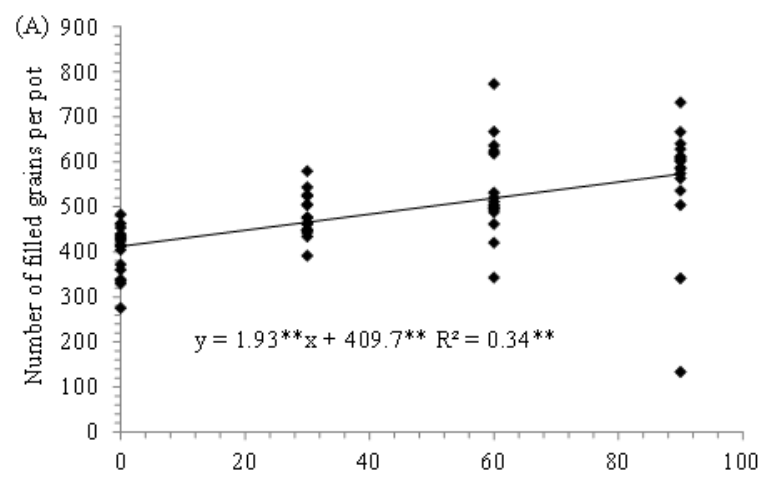

respectively. The cultivar BRS Sertaneja presented the same behavior regarding filled grains in a research of Barreto et al. (2012). However, in a study by Fabre et al. (2011) and Buzetti et al. (2006), increase in rice yield as a function of $\mathrm{N}$ dose was quadratic. This indicates that the doses of $\mathrm{N}$ tested in the present study did not reach the dose which provides maximum rice yield.

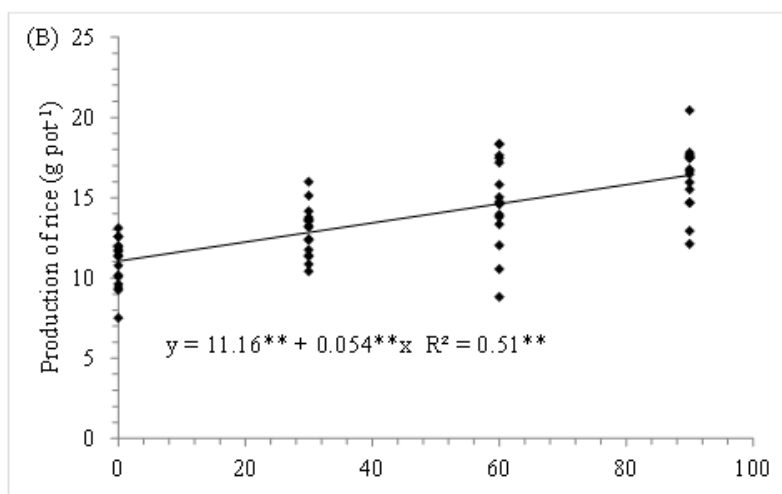

Figure 1. Effect of doses of nitrogen on number of filled grains of rice per pot (A) and production of rice per pot (B). $(* *$ significant at $1 \%$ of probability).

In general, increase in the doses of $\mathrm{N}$ raises rice yields due to the increase in the number of filled grains (MINGOTTE; HANASHIRO; FORNASIERI FILHO, 2013). Apart from the dose, whose increase promotes increase in the number of spikelets and filled spikelets, the moment of $\mathrm{N}$ application is critical for the yield (YOSEFTABAR, 2013). However, yield increase depends on a balance between number of panicles per area and number of filled grains per panicle, and this balance can be modified by increased $\mathrm{N}$ doses (BARRETO et al., 2012).

Interaction between $\mathrm{N}$ doses and biochar doses was significant $(\mathrm{p}<0.01)$ for the variables DSM and NEG (Table 2), whereas MHG showed only a significant effect $(\mathrm{p}<0.05)$ of $\mathrm{N}$ doses interacting with doses of 7,000 and $10,500 \mathrm{~kg} \mathrm{ha}^{-1}$ of biochar, and NP showed only a significant effect of $\mathrm{N}$ doses $(\mathrm{p}<0.01)$ within the doses of 0 and $10,500 \mathrm{~kg} \mathrm{ha}^{-1}$. The ability of biochar to improve $\mathrm{N}$ use efficiency in plants has been demonstrated in Chan et al. (2007), who observed increased productivity of radish in pots due to the application of biochar in the presence of nitrogen. This ability can potentially result in economic and environmental benefits due to reduced $\mathrm{N}_{2} \mathrm{O}$ emissions and losses of inorganic $\mathrm{N}$ via leaching (NÓBREGA, 2011).

Highest $\mathrm{N}$ use efficiency (using $\mathrm{N}$ that is mobile in the soil-plant system and is lost easily through leaching, volatilization, and denitrification) (FABRE et al., 2011) can be provided by the synchrony between $\mathrm{N}$ demands of the crop and $\mathrm{N}$ supply by the soil or through fertilization (YOSEFTABAR, 2013). According to Yoshida (1981), zeolite is used in Japan to increase the soil's capacity of $\mathrm{N}$ retention and, consequently, increase rice yields. Steiner et al. (2010) reported that retention of $\mathrm{NH}_{4}-\mathrm{N}$ by biochar explains the large $\mathrm{N}$ recovery in soils where it was applied. Therefore, soil $\mathrm{N}$ retention capacity determines the splitting of the applied $\mathrm{N}$ fertilizer doses. In contrast, Ding et al. (2010) reported evidences that biochar can be used in the soil as an additive capable of retaining nutrients, thereby increasing the efficiency of chemical fertilizers.

Table 2. Effect of interaction, indicated by test $\mathrm{F}$, of doses of nitrogen within each dose of biochar $\left(\mathrm{kg} \mathrm{ha}^{-1}\right)$ on production variables of upland rice.

\begin{tabular}{|c|c|c|c|c|}
\hline & $\mathrm{D}_{0}$ & $\mathrm{D}_{1}$ & $\mathrm{D}_{2}$ & $\mathrm{D}_{3}$ \\
\hline & \multicolumn{4}{|c|}{ Dry shoot mass $\left(\mathrm{g} \mathrm{pot}^{-1}\right)$} \\
\hline Effect of $N$ & $14.62 * *$ & $20.04 * *$ & $11.50 * *$ & $18.34 * *$ \\
\hline Mean & 20.71 & 19.70 & 20.42 & 19.66 \\
\hline \multirow[t]{2}{*}{$\mathrm{CV}(\%)$} & 7.18 & 5.46 & 9.96 & 9.92 \\
\hline & \multicolumn{4}{|c|}{ Mass of hundred grains $(\mathrm{g})$} \\
\hline Effect of $\mathrm{N}$ & $1.43^{\mathrm{ns}}$ & $0.93^{\mathrm{ns}}$ & $3.39^{*}$ & $3.80^{*}$ \\
\hline Mean & 2.84 & 2.82 & 2.79 & 2.79 \\
\hline CV $(\%)$ & 4.36 & 377 & 5.07 & 3.03 \\
\hline
\end{tabular}

**significant at $1 \%$ of probability; *significant at $5 \%$; ${ }^{\mathrm{ns}}$ non-significant. $\mathrm{D}_{0}=0 \mathrm{~kg} \mathrm{ha}^{-1} ; \mathrm{D}_{1}=3,500 \mathrm{~kg} \mathrm{ha}^{-1} ; \mathrm{D}_{2}=7,000 \mathrm{~kg} \mathrm{ha}^{-1}$, and $\mathrm{D}_{3}=10,500 \mathrm{~kg} \mathrm{ha}^{-1}$ of biochar. 
Table 2. Continuation.

\begin{tabular}{lcccc}
\hline & $\mathrm{D}_{0}$ & $\mathrm{D}_{1}$ & $\mathrm{D}_{2}$ & $\mathrm{D}_{3}$ \\
\cline { 2 - 5 } & \multicolumn{4}{c}{ Number of panicles per pot } \\
\hline Effect of N & $5.53^{* *}$ & $0.56^{\text {ns }}$ & $1.89^{\text {ns }}$ & $7.10^{* *}$ \\
Mean & 7.62 & 7.44 & 7.44 & 6.87 \\
CV $(\%)$ & 14.66 & 15.40 & 15.65 & 19.47 \\
\hline \multicolumn{4}{c}{ Number of empty grains per pot } \\
\hline Effect of N & $19.92^{* *}$ & $19.50^{* *}$ & $7.27^{* *}$ & $5.87^{* *}$ \\
Mean & 15.29 & 3.85 & 13.86 & 13.24 \\
CV $(\%)$ & 16.57 & 10.08 & 16.66 & 25.89 \\
\hline
\end{tabular}

**significant at $1 \%$ of probability; *significant at $5 \%$; ${ }^{\text {ns }}$ non-significant. $\mathrm{D}_{0}=0 \mathrm{~kg} \mathrm{ha}^{-1} ; \mathrm{D}_{1}=3,500 \mathrm{~kg} \mathrm{ha}^{-1} ; \mathrm{D}_{2}=7,000 \mathrm{~kg} \mathrm{ha}^{-1}$, and $\mathrm{D}_{3}=10,500 \mathrm{~kg} \mathrm{ha}^{-1}$ of biochar.

The quadratic effect of $\mathrm{N}$ on DSM was observed for doses of 0 and $3,500 \mathrm{~kg} \mathrm{ha}^{-1}$ of biochar, both with a point of maximum at $67.5 \mathrm{~kg} \mathrm{ha}^{-1}$ of $\mathrm{N}$ (Figure 2A), with the higher values of DSM occurring at the dose zero of biochar. However, the effect of the $\mathrm{N}$ doses was linear positive for the doses of 7,000 and $10,500 \mathrm{~kg} \mathrm{ha}^{-1}$ of biochar, which values
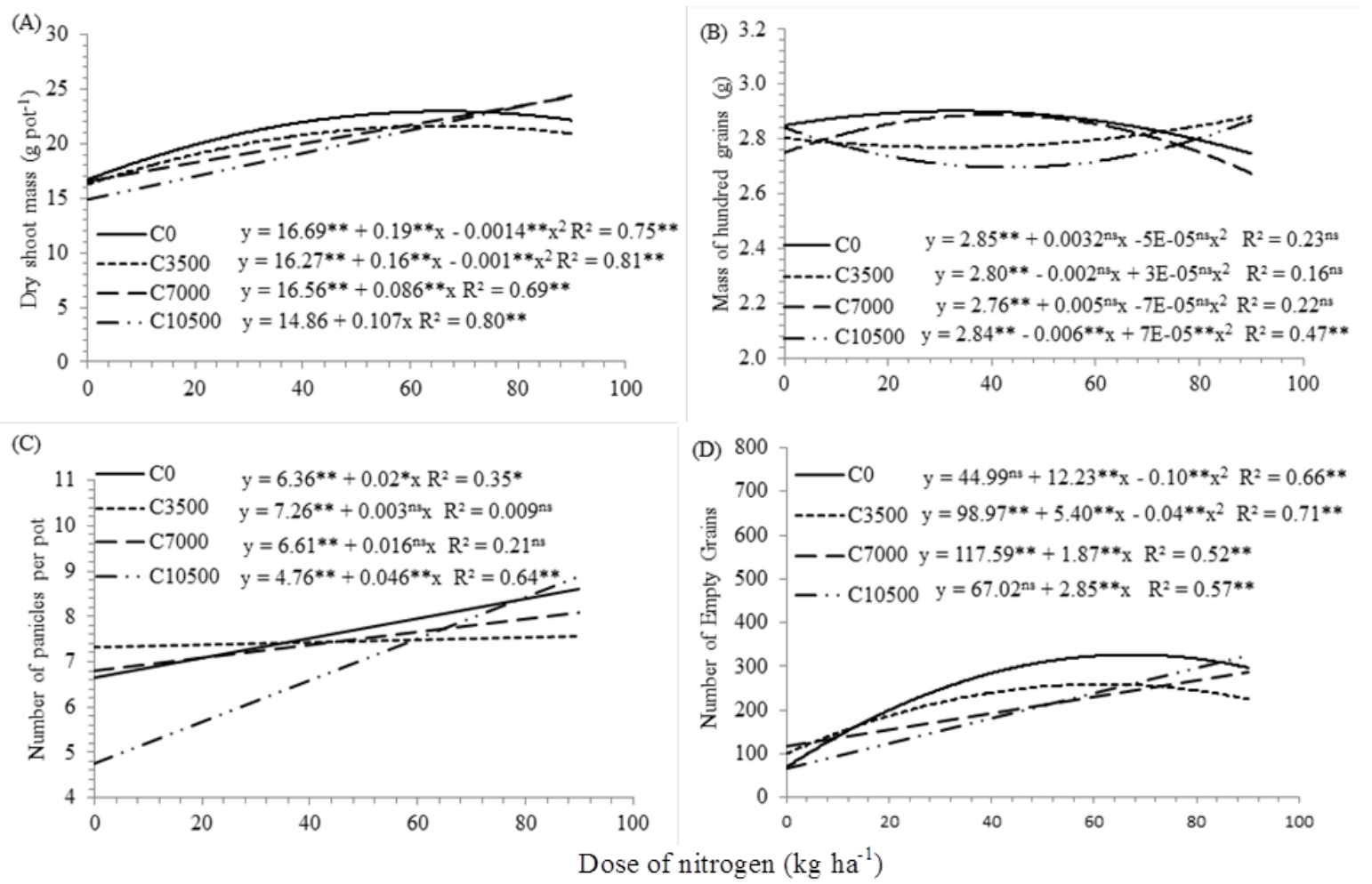

Figure 2. Effect of the interaction of nitrogen doses and biochar doses on dry shoot mass $\left(\mathrm{g}\right.$ pot $\left.{ }^{-1}\right)(\mathrm{A})$, mass of hundred grains (g) (B), number of panicles per pot (C), and number of empty grains per pot (D). (**significant at $1 \%$ of probability; *significant at $5 \%$; ${ }^{\mathrm{ns}}$ non-significant).

When biochar was not applied, an increase of $36 \%$ in DSM was obtained with the dose of $90 \mathrm{~kg} \mathrm{ha}^{-1}$ of $\mathrm{N}$ compared to no $\mathrm{N}$ application, whereas when we applied $3,500 \mathrm{~kg} \mathrm{ha}^{-1}$ of biochar, the increase was $31 \%$. The application of $7,000 \mathrm{~kg} \mathrm{ha}^{-1}$ of biochar provided increases of $27.5 \%$ for the dose of $30 \mathrm{~kg} \mathrm{ha}^{-1}$ of $\mathrm{N}$ compared to no $\mathrm{N}$ application, and of $52 \%$ for the dose of $90 \mathrm{~kg} \mathrm{ha}^{-1}$ of N. However, higher DSM values were obtained when we applied $90 \mathrm{~kg} \mathrm{ha}^{-1}$ of $\mathrm{N}$ combined with a dose of $10,500 \mathrm{~kg} \mathrm{ha}^{-1}$ of biochar, resulting in an

of dry mass become higher than values for the doses of 0 and $3,500 \mathrm{~kg} \mathrm{ha}^{-1}$ near the point of maximum of these two doses. A beneficial effect of biochar application of biochar on growth and dry mass accumulation of upland rice was also observed by Madari et al. (2006).

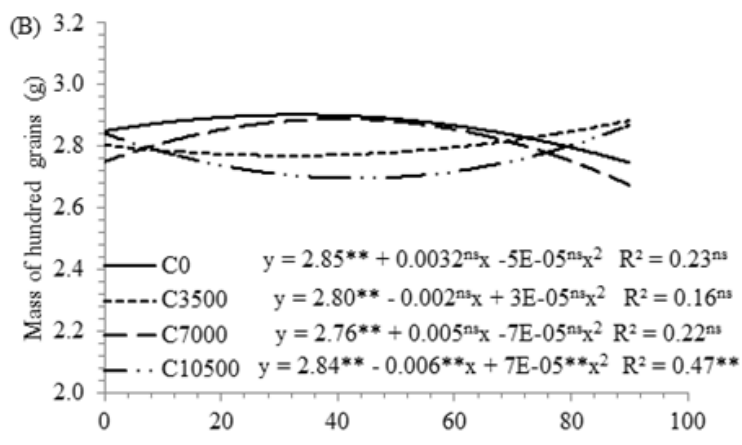


using $\mathrm{N}$ doses which significantly interacted with biochar doses. At a dose of 7,000 $\mathrm{kg} \mathrm{ha}^{-1}$ of biochar, the effect was quadratic as a function of the $\mathrm{N}$ dose (Figure 2B), reaching a maximum at a dose of $36 \mathrm{~kg} \mathrm{ha}^{-1}$ of $\mathrm{N}$, while at a dose of $10,500 \mathrm{~kg} \mathrm{ha}^{-1}$, minimum values were obtained with $43 \mathrm{~kg} \mathrm{ha}^{-1}$ of $\mathrm{N}$. Considering that the regression for the dose of $7,000 \mathrm{~kg} \mathrm{ha}^{-1}$ of biochar did not result in equation with significant parameters, the regression for the dose of $10,500 \mathrm{~kg} \mathrm{ha}^{-1}$ indicates that MHG decreases with smaller $\mathrm{N}$ doses, but for doses higher than $43 \mathrm{~kg} \mathrm{ha}^{-1}$, part of $\mathrm{N}$ was retained by biochar, positively impacting grain filling.

In this respect, Yoseftabar (2013) noted that split application of the nitrogen fertilizer promoted higher grain mass, thereby increasing yields. However, Barreto et al. (2012) did not observe significant effects of $\mathrm{N}$ doses on the MHG of the upland rice cultivar BRS Sertaneja, similarly to Zhang et al. (2008) who working with other rice varieties. There are also reports of reductions in mass of 100 grains with increasing levels of N (BUZETTI et al., 2006; MINGOTTE; HANASHIRO; FORNASIERI FILHO, 2013). According to Kischel et al. (2011) this can be due to excess nitrogen, resulting in luxury consumption in which the plant prioritizes growth at the expense of grain mass.

Nitrogen fertilization in combination with 0 and $10,500 \mathrm{~kg} \mathrm{ha}^{-1}$ of biochar linearly positively affected panicle numbers in upland rice (Figure 2C), while the regressions for the other doses were not significant. Linear increase in the number of panicles per area of the same cultivar, BRS Sertaneja, was also observed by Barreto et al. (2012) when all N doses were applied at planting. In contrast, Fabre et al. (2011) verified quadratic effect of $\mathrm{N}$ doses on the number of panicles. In the present work, when biochar was not applied, a 52\% increase in the number of panicles was observed when $\mathrm{N}$ doses increased from 0 to $30 \mathrm{~kg} \mathrm{ha}^{-1}$, whereas with the dose of $10,500 \mathrm{~kg} \mathrm{ha}^{-1}$ of biochar, the increase was $50 \%$ between the dose 0 and the dose of $60 \mathrm{~kg} \mathrm{ha}^{-1}$ of $\mathrm{N}$ and $80 \%$ between the dose 0 and the dose of $90 \mathrm{~kg} \mathrm{ha}^{-1}$ of $\mathrm{N}$.

According to Buzetti et al. (2006), who observed a positive response of rice to nitrogen fertilization in terms of number of panicles per area and number of grains per panicle, panicle number per area is directly related to rice productivity. In a similar study, Mingotte, Hanashiro and Fornasieri Filho (2013) stated that variables related to panicles are determined by the application of nitrogen, e.g. the number of panicles which increases significantly with nitrogen fertilization. As panicle number is determined during germination, it can only be increased by the application of nitrogen at the beginning of the growth cycle (BUZETTI et al., 2006; FABRE et al., 2011; YOSEFTABAR, 2013).

The highest number of empty grains was observed when no biochar was added, in which case the doses of $\mathrm{N}$ has a quadratic impact and $\mathrm{NEG}$ reached maximum levels at $61 \mathrm{~kg} \mathrm{ha}^{-1}$ of $\mathrm{N}$ (Figure 2D). A dose of $3,500 \mathrm{~kg} \mathrm{ha}^{-1}$ of biochar resulted in lower NEG levels than the dose zero and presented a point of maximum at $67 \mathrm{~kg} \mathrm{ha}^{-1}$ of $\mathrm{N}$. However, NEG increased linearly with increasing $\mathrm{N}$ doses. The quadratic increase in percentage of sterile spikelets of BRS Sertaneja as a function of the doses of N was also observed by Barreto et al. (2012), while Buzetti et al. (2006) observed a linear increase when testing other varieties. The coal-free treatment demonstrates the isolated effect of $\mathrm{N}$, where increased doses cause increase in sterility of spikelets up to a maximum level. This effect is attenuated with a dose of $3,500 \mathrm{~kg} \mathrm{ha}^{-1}$ of biochar, due to partial $\mathrm{N}$ retention. However, with higher biochar doses, NEG increased linearly with increased $\mathrm{N}$ doses, due to a greater retention of nitrogen which is released slowly, maintaining an excess of $\mathrm{N}$ in the soil.

The lower fertility of rice spikelets due to increased $\mathrm{N}$ doses is related to the fact that this nutrient provides higher spikelet numbers per panicle. Therefore, low spikelet sterility under high doses of $\mathrm{N}$ is an important criterion in the selection of rice genotypes (BARRETO et al., 2012; MINGOTTE; HANASHIRO; FORNASIERI FILHO, 2013). Decrease in spikelet sterility is one of the causes of the increase in yield when the application of $\mathrm{N}$ is split. This reduction occurs when $\mathrm{N}$ is applied after spikelet differentiation, because the upper leaves remain upright and more efficiently use the photosynthetically active radiation (MINGOTTE; HANASHIRO; FORNASIERI FILHO, 2013; YOSEFTABAR, 2013).

\section{Cowpea Production Variables}

The production variables of cowpea showed no significant effect (test $\mathrm{F}-\mathrm{p}<0.05$ ) of biochar doses or interactions between biochar and $\mathrm{N}$ application. These variables, presented in Table 3, presented coefficients of variation (CV) between 24 and $28 \%$, which are considered medium. Different results were obtained by Silva et al. (2011) with common bean; they observed increased yields with a dose of $32 \mathrm{Mg} \mathrm{ha}^{-1}$ of biochar.

The significant effect of $\mathrm{N}$ doses on the production of cowpea per pot (Table 3 ) indicates that the dose of $90 \mathrm{~kg} \mathrm{ha}^{-1}$ of $\mathrm{N}$ was detrimental to the crop. In this respect, Oliveira et al. (2003) achieved maximum cowpea yields with the dose of $60 \mathrm{~kg} \mathrm{ha}^{-1}$ of N. On the other hand, Dutra et al. (2012) did not observe any effects of nitrogen fertilization on cowpea yield and therefore state that $\mathrm{N}$ addition is not always beneficial to productivity. This, according to Martins et al. (2013), may be because high $\mathrm{N}$ doses stimulate the vegetative development of cowpea at the cost of grain production. 
Table 3. Means of grain production per pot (PRODC - g), number of pods per pot (NPP), and grain number per pod (NGP) of cowpea under doses of biochar and nitrogen.

\begin{tabular}{rccc}
\hline \multicolumn{1}{c}{ Dose } & PRODC & NPP & NGP \\
\hline \multicolumn{4}{c}{ Effect of biochar dose $\left(\mathrm{kg} \mathrm{ha}^{-1}\right)$} \\
3500 & 5.77 & 6.25 & 3.91 \\
7000 & 6.41 & 6.63 & 4.41 \\
10500 & 5.56 & 5.88 & 4.08 \\
\hline \multicolumn{4}{c}{ Effect of nitrogen dose $\left(\mathrm{kg} \mathrm{ha}^{-1}\right)$} \\
\hline 0 & $6.69 \mathrm{~A}$ & $6.25 \mathrm{~A}$ \\
90 & $5.08 \mathrm{~B}$ & $5.94 \mathrm{~A}$ & $4.56 \mathrm{~A}$ \\
\hline
\end{tabular}

Means followed by different letters differ by the Duncan's test $(\mathrm{p}<0.05)$.

\section{Soil Chemical Characteristics}

Analysis of variance did not indicate significant effects for contents of $\mathrm{Ca}$ and $\mathrm{Mg}$ and for soil cation exchange capacity (CEC). In relation to the content of $\mathrm{Na}$, despite the significant effect of biochar doses, exchangeable sodium percentage (ESP) is more suitable to indicate the effects of salinization on the soil and the crops, according to Andrade Júnior et al. (2006). Therefore, we only discuss the variables $\mathrm{pH}$, ESP, levels of organic carbon (CORG), $\mathrm{P}, \mathrm{K}$, and calcium and magnesium (CAMG). Most of these variables showed significant differences between the two samplings at the $1 \%$ probability level, with the exception of $\mathrm{P}(\mathrm{p}<0.05)$, whereas the effect of biochar was not significant for phosphorous content and ESP. The application of biochar to the soil is considered as a way of sequestering carbon and also of improving soil functions (VERHEIJEN et al., 2010). Some beneficial characteristics of biochar as a soil conditioner are its high cation exchange capacity, high specific surface, and affinity for macro- and micronutrients.

Joint regression analysis for the two seasons did not provide equations with significant parameters for soil chemical characteristics. However, comparison of means (Table 4) demonstrates that the values of $\mathrm{pH}, \mathrm{K}$, and $\mathrm{CAMG}$ decreased from the first to the second crops, which may be due to leaching of nutrients and their consumption by the crops. On the other hand, increases in CORG and P may be due to their greater availability to the soil; alternatively, the reaction of carbon with the soil allowed its detection by the methodology employed. The increase in ESP was due to increased $\mathrm{Na}$ levels and decreases in calcium and magnesium.

Among the variables which significantly increased between the lowest and highest doses of biochar in the two samplings (Table 4), the largest increase was observed for $\mathrm{K}$, with $46 \%$, while $\mathrm{pH}$ increased by $5 \%$. Although not statistically significant, the increase in soil $\mathrm{P}$ was $29 \%$. In a similar study by Carvalho et al. (2013), the authors did not observe any effects of coal on levels of $P$ and organic carbon. However, increases of soil $\mathrm{P}$ were observed by Chan et al. (2007) in pot experiments and by Silva et al. (2011). According to Madari et al. (2006), increased soil P levels may be due to the release of this element by biochar when in organic linkage with different forms of organic matter, while when in inorganic linkage with clay minerals in the soil, it is unavailable to plants. In a previous study by Petter et al. (2012), soil P availability increased by $17 \%$ with a dose of $32 \mathrm{Mg} \mathrm{ha}^{-1}$ of biochar in relation to the control. According to Sohi et al. (2010), an indirect effect of biochar on soil $\mathrm{P}$ availability, besides the content of $\mathrm{P}$ in the ash fraction of biochar, can explain the short-term effects of biochar application.

Table 4. Comparison of means of soil chemical variables for both sampling dates and doses of biochar applied to the soil.

\begin{tabular}{|c|c|c|c|c|c|c|}
\hline & $\mathrm{pH}$ & CORG & $\mathrm{P}$ & $\mathrm{K}$ & CAMG & ESP \\
\hline \multicolumn{7}{|c|}{ Effect of sampling date } \\
\hline 1 & $6.63 \mathrm{~A}$ & $1.04 \mathrm{~B}$ & $15.99 \mathrm{~B}$ & $50.04 \mathrm{~A}$ & $2.37 \mathrm{~A}$ & $12.64 \mathrm{~B}$ \\
\hline 2 & $5.56 \mathrm{~B}$ & $1.40 \mathrm{~A}$ & $20.61 \mathrm{~A}$ & $29.14 \mathrm{~B}$ & $1.08 \mathrm{~B}$ & $22.74 \mathrm{~A}$ \\
\hline \multicolumn{7}{|c|}{ Effect of biochar dose $\left(\mathrm{kg} \mathrm{ha}^{-1}\right)$} \\
\hline 0 & $5.91 \mathrm{C}$ & $1.34 \mathrm{~A}$ & $16.67 \mathrm{~A}$ & $33.52 \mathrm{~B}$ & $1.77 \mathrm{AB}$ & $17.48 \mathrm{AB}$ \\
\hline 3,500 & $6.06 \mathrm{~B}$ & $1.20 \mathrm{AB}$ & $17.12 \mathrm{~A}$ & $36.52 \mathrm{~B}$ & $1.81 \mathrm{~A}$ & $15.59 \mathrm{~B}$ \\
\hline 7,000 & $6.17 \mathrm{AB}$ & $1.28 \mathrm{AB}$ & $18.16 \mathrm{~A}$ & $30.09 \mathrm{~B}$ & $1.61 \mathrm{~B}$ & $18.17 \mathrm{AB}$ \\
\hline 10,500 & $6.22 \mathrm{~A}$ & $1.08 \mathrm{~B}$ & $21.50 \mathrm{~A}$ & $48.98 \mathrm{~A}$ & $1.71 \mathrm{AB}$ & $19.30 \mathrm{~A}$ \\
\hline${ }^{1}$ Difference & 5.25 & -24.07 & 28.97 & 46.12 & -3.51 & 10.41 \\
\hline
\end{tabular}

$\mathrm{CORG}=$ organic carbon; $\mathrm{CAMG}=$ sum of $\mathrm{Ca}$ and $\mathrm{Mg}$ contents; $\mathrm{ESP}=$ exchangeable sodium percentage. ${ }^{1}$ Difference $(\%)$ between the mean of dose zero and the highest mean. Means followed by different letters differ significantly by Duncan's test $(\mathrm{p}<0.05)$. 
The decrease of $24 \%$ in the organic carbon content of the soil, even after the application of biochar containing $63 \%$ of carbon, may be due to the methodology employed (Walkley-Black modified). Madari et al. (2006) also used this method and claim that it only quantifies oxidizable organic matter, while biochar, which is a more stable form of organic matter, is rarely quantified.

In the first sampling, we verified the significant effect of biochar dose on $\mathrm{pH}$, CAMG $(\mathrm{p}<0.05)$, and $\mathrm{K}(\mathrm{p}<0.01)$, which presented a CV of $50 \%$. However, there was no significant effect of $\mathrm{N}$ doses (30 and $\left.60 \mathrm{~kg} \mathrm{ha}^{-1}\right)$ or the interaction between doses of carbon and of nitrogen. Although Silva et al. (2011) affirm that in case of a short time of interaction between soil and biochar, the effect of biochar on soil chemical properties is lower than expected, Madari et al. (2006) observed significant effects 28 days after biochar application.

The increase in soil $\mathrm{pH}$, as observed in this study, is the most quoted chemical change resulting from biochar application and is, according to Jeffery et al. (2011), one of its main positive effects, besides the promotion of indirect effects on soil chemistry (SOHI et al., 2010). The corrective effect of soil acidity, according to Verheijen et al. (2010), is one of the most probable mechanisms to increase crop yields after application of biochar to the soil. According to Wang et al. (2014), the main factors in neutralization of soil acidity are the association of $\mathrm{H}^{+}$ ions with the biochar and decarboxylation processes. In this respect, a study of Petter et al. (2012) showed that the positive effect of application of coal on the soil $\mathrm{pH}$ increased with increased biochar doses.

The effect of biochar dose on soil $\mathrm{pH}$ was linear positive (Figure 3A), leading to an increase of $6 \%$ in $\mathrm{pH}$ between the doses zero and $10,500 \mathrm{~kg} \mathrm{ha}^{-1}$ of biochar. For K, the effect of biochar dose was quadratic (Figure 3B), with an increase of $73 \%$ between the lowest and highest doses of biochar. The effect on CAMG was also quadratic (Figure 3C) and showed a reduction of around $10 \%$ in CAMG contents. Although not statistically significant, an increase of $40 \%$ for $\mathrm{P}$ and a reduction of $62 \%$ in soil organic carbon were observed.

In a research by Streubel et al. (2011), the application of biochar to the soil, irrespective of its origin, significantly increased $\mathrm{pH}$ values of all soil types studied, with higher effects in sandy soil. In another study, Chan et al. (2007) observed that biochar applications provided an increase in soil $\mathrm{pH}$ of 1.22 units between the doses zero and $100 \mathrm{Mg} \mathrm{ha}^{-1}$ in the absence of nitrogen fertilizer and 0.61 units when nitrogen fertilizer was applied. Verheijen et al. (2010) performed a statistical meta-analysis of studies on the yields of diverse crops and observed that, on average, soil $\mathrm{pH}$ increased from 5.3 before application of biochar to 6.2 after application. The authors emphasized the use of biochar from cattle manure that promoted an increase in $\mathrm{pH}$ from 4.8 to 7.8 .

In relation to increased soil $\mathrm{K}$ values during the duration of this experiment, Jeffery et al. (2011) state that higher nutrient availability, in particular K, is one of the main positive effects of biochar application on crop yields, apart from higher water retention and soil acidity reduction. Increased plant-available potassium through biochar application was also observed by Madari et al. (2006), Chan et al. (2007), and Silva et al. (2011).

Analysis of the data of the second sampling showed a significant effect of biochar doses only on the variables $\mathrm{pH}(\mathrm{p}<0.01)$, CAMG, and ESP $(p<0.05)$, whereas as effect of $\mathrm{N}$ doses was observed for $\mathrm{pH}$ and ESP, without significant interactions. Our results differ from those obtained by Petter et al. (2012), who had observed an effect of biochar on $\mathrm{K}$ availability only in the second year of the experiment. According to these authors, biochar contains considerable amounts of $\mathrm{K}$ and other nutrients. Increased soil $\mathrm{K}$ values were also observed by Carvalho et al. (2013); however, this increase was dependent on the $\mathrm{N}$ dose applied.

The effect of biochar dose on $\mathrm{pH}, \mathrm{CAMG}$, and ESP was quadratic (Figure 4). When the dose of biochar was increased from 0 to $10,500 \mathrm{~kg} \mathrm{ha}^{-1}$, increases of $7 \%$ in $\mathrm{pH}$ and $19 \%$ in ESP were observed, whereas CAMG decreased by around $9 \%$. The increase in ESP after application of biochar was due to increased soil sodium values (not presented) and decreased calcium and magnesium values. Although not statistically significant, increases around $23 \%$ in the content of $\mathrm{P}$ and $27 \%$ in $\mathrm{K}$ were observed between the lowest and highest doses of biochar.

The observed reduction in the contents of calcium $(\mathrm{Ca})$ and magnesium $(\mathrm{Mg})$ of the soil, which could have been dislocated from the sites of exchange to the soil solution and then leached, is in accordance with results found by Silva et al. (2011), who observed increased $\mathrm{K}$ and $\mathrm{P}$ values and reduced $\mathrm{Ca}$ and $\mathrm{Mg}$ concentrations in the soil after application of biochar. However, in contrast, Chan et al. (2007) observed that the use of high doses of biochar increased exchangeable cations. In this respect, Carvalho et al. (2013) observed linear increases of $\mathrm{Ca}$ and $\mathrm{Mg}$ in the soil due to increased biochar does, whereas Petter et al. (2012) observed increases of $36 \%$ in the calcium content of the soil when biochar was applied at a dose of $32 \mathrm{Mg} \mathrm{ha}^{-1}$ in relation to the control; however, they could not verify the effect of biochar application on the magnesium content in the first year of the experiment. 

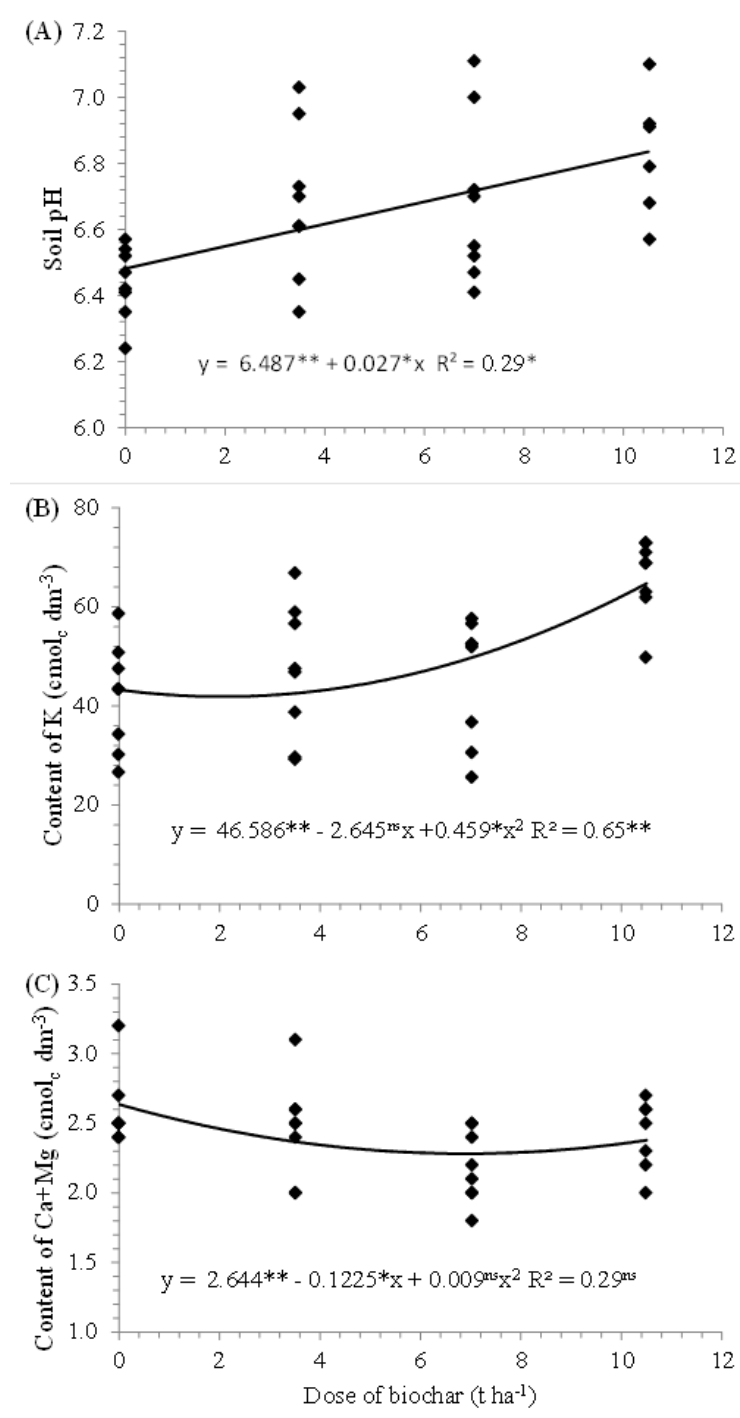

Figure 3. Effect of biochar doses on soil $\mathrm{pH}(\mathrm{A})$, potassium content (B), and content of calcium and magnesium (C) in the first soil sampling. (**significant at $1 \%$ of probability; *significant at $5 \%$; ${ }^{\text {ns }}$ non-significant).
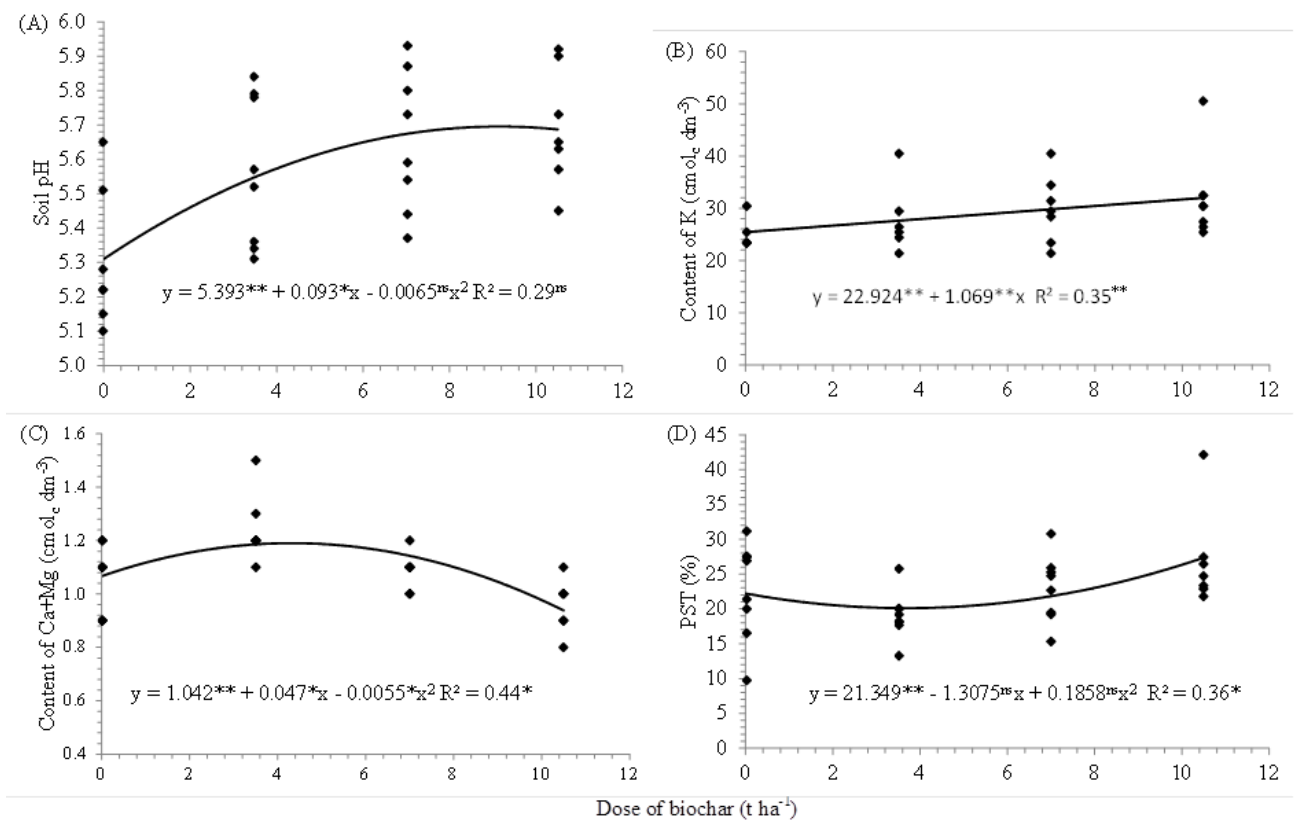

Figure 4. Effect of biochar dose on soil pH (A), content of potassium (B), content of calcium and magnesium (C), and ESP (D) in the second soil sampling. (** significant at $1 \%$ of probability; *significant at $5 \%$; ${ }^{\text {ns }}$ non-significant). 
Soil $\mathrm{pH}$ increased by $5 \%$ when a dose of $90 \mathrm{~kg} \mathrm{ha}{ }^{-1}$ of $\mathrm{N}$ was applied, compared to no application of biochar (Table 5). In the case of ESP, we observed a $27 \%$ reduction when the dose was increased from 0 to $90 \mathrm{~kg} \mathrm{ha}^{-1}$. These results can be explained by the application of calcium nitrate as $\mathrm{N}$ source.

In relation to the increase of ESP promoted by the application of biochar in the present work, which was also observed by Chan et al. (2007) in pot experiments, Verheijen et al. (2010) state that the salts contained in biochar can be a potential source of secondary salinization. According to these authors, the composition of salts in the ash fraction of the biochar is highly dependent on the composition of its feedstock, although sodium is contained in lower amounts in relation to other minerals. The authors also point out the fact that there is little research on the ashes of the biochar and on the possibility of the salts becoming soluble and contributing to soil salinization.

Table 5. Comparison of means between doses of nitrogen for the soil chemical variables in the second sampling.

\begin{tabular}{ccccccc}
\hline Dose & $\mathrm{pH}$ & CORG & $\mathrm{P}$ & $\mathrm{K}$ & CAMG & ESP \\
\hline $0 \mathrm{~kg} \mathrm{ha}^{-1}$ & $5.43 \mathrm{~B}$ & $1.33 \mathrm{~B}$ & $21.84 \mathrm{~A}$ & $30.51 \mathrm{~A}$ & $1.07 \mathrm{~A}$ & $25.33 \mathrm{~A}$ \\
$90 \mathrm{~kg} \mathrm{ha}^{-1}$ & $5.68 \mathrm{~A}$ & $1.46 \mathrm{~A}$ & $19.37 \mathrm{~A}$ & $28.14 \mathrm{~A}$ & $1.09 \mathrm{~A}$ & $19.88 \mathrm{~B}$ \\
\hline
\end{tabular}

$\mathrm{CORG}=$ organic carbon; $\mathrm{CAMG}=$ sum of $\mathrm{Ca}$ and $\mathrm{Mg}$ contents; $\mathrm{ESP}=$ exchangeable sodium percentage. Means followed by different letters differ significantly by Duncan's test $(\mathrm{p}<0.05)$.

\section{CONCLUSIONS}

Application of biochar has no impact on the production of upland rice and cowpea.

Application of biochar improves soil $\mathrm{N}$ retention, which influences the shoot dry mass of rice, sterility of spikelets, number of panicles, and grain mass.

Application of biochar promotes increased $\mathrm{pH}$, potassium content, and soil exchangeable sodium percentage, along with a decrease in calcium and magnesium contents.

\section{REFERENCES}

ANDRADE JÚNIOR, A. S. et al. Uso e qualidade da água subterrânea para irrigação no semi-árido piauiense. Revista Brasileira de Engenharia Agrícola e Ambiental, Campina Grande, v. 10, n. 4, p. 873-880, 2006.

BARRETO, J. H. B. et al. Yield performance of upland rice cultivars at different rates and times of nitrogen application. Revista Brasileira de Ciência do Solo, Viçosa, v. 36, n. 2, p. 475-483, 2012.

BUZETTI, S. et al. Resposta de cultivares de arroz a doses de nitrogênio e do regulador de crescimento cloreto de clormequat. Pesquisa Agropecuária Brasileira, Brasília, v. 41, n. 12, p. 1731-1737, 2006.

CARVALHO, M. T. M. et al. Biochar improves soil fertility of a clay soil in the Brazilian Savannah: short term effects and impact on rice yield. Journal of Agriculture and Rural Development in the Tropics and Subtropics, Witzenhausen, v. 114, n. 1, p. 101-107, 2013.

CHAN, K. Y. et al. Agronomic values of greenwaste biochar as a soil amendment. Soil Research, Canberra, v. 45, n. 8, p. 629-634, 2007.

DING, Y. et al. Evaluation of biochar effects on nitrogen retention and leaching in multi-layered soil columns. Water, Air \& Soil Pollution, Dordrecht, v. 213, n. 1-4, p. 47-55, 2010

DUTRA, A. S. et al. Produtividade e qualidade fisiológica de sementes de feijão caupi em função da adubação nitrogenada. Revista Ciência Agronômica, Fortaleza, v. 43, n. 4, p. 816-821, 2012.

EMPRESA BRASILEIRA DE PESQUISA AGROPECUÁRIA - EMBRAPA. Manual de análises químicas de solos, plantas e fertilizantes. 2. ed. Brasília, DF: Embrapa Informação Tecnológica, 624 p. 2009.

FABRE, D. V. O. et al. Doses e épocas de aplicação de nitrogênio em arroz de várzea. Pesquisa Agropecuária Tropical, Goiânia, v. 41, n. 1, p. 29-38, 2011

FOOD AND AGRICULTURE ORGANIZATION OF THE UNITED NATIONS - FAO. The state of the world's land and water resources for food and agriculture. Managing systems at risk. Summary Report. Rome, 2011. 47 p.

JANZEN, H. H. The soil carbon dilemma: Shall we hoard it or use it? Soil Biology \& Biochemistry, Amsterdam, v. 38, n. 3, p. 419-424, 2006.

JEFFERY, S. et al. A quantitative review of the effects of biochar application to soils on crop productivity using meta-analysis. Agriculture, Ecosystems \& Environment, Amsterdam, v. 144, n. 1, p. 175-187, 2011. 
KISCHEL, E. et al. Efeito do Nitrogênio em genótipos de arroz cultivados em várzea úmida do Estado do Tocantins. Revista Ceres, Viçosa, v. 58, n. 1, p. 84-89, 2011.

LINHARES, C. R. et al. Reproducing the organic matter model of anthropogenic dark earth of Amazonia and testing the ecotoxicity of functionalized charcoal compounds. Pesquisa Agropecuária Brasileira, Brasília, v. 47, n. 5, p. 693-698, 2012.

MADARI, B. E. et al. Carvão vegetal como condicionador de solo para arroz de terras altas (cultivar Primavera): um estudo prospectivo. Santo Antônio de Goiás: Embrapa Arroz e Feijão, 2006. 6 p. (Comunicado Técnico, 125).

MAIA, C. M. F.; MADARI, B. E.; NOVOTNY, E. $\mathrm{H}$. Advances in biochar research in Brazil. Dynamic Soil, Dynamic Plant, Kagawa, v. 5, n. 1, p. 53-58, 2011.

MARTINS, R. N. L. et al. Nitrogênio e micronutrientes na produção de grãos de feijão-caupi inoculado. Semina: Ciências Agrárias, Londrina, v. 34, n. 4, p. 1577-1586, 2013.

MINGOTTE, F. L. C.; HANASHIRO, R. K.; FORNASIERI FILHO, D. Response of rice cultivars to nitrogen in upland conditions. Revista Ceres, Viçosa, v. 60, n. 1, p. 86-95, 2013.

NÓBREGA, I. P. C. Efeitos do biochar nas propriedades físicas e químicas do solo: sequestro de carbono no solo. 2011. 38 f. Dissertação (Mestrado em Engenharia do Ambiente) Universidade Técnica de Lisboa, Lisboa, 2011.

OLIVEIRA, A. P. et al. Rendimento de feijão-caupi em função de doses e formas de aplicação de nitrogênio. Horticultura Brasileira, Brasília, v. 21, n. 1, p. 77-80, 2003.

PETTER, F. A. et al. Soil fertility and upland rice yield after biochar application in the Cerrado. Pesquisa Agropecuária Brasileira, Brasília, v. 47, n. 5, p. 699-706, 2012.

SANTOS, H. G. et al. Sistema Brasileiro de Classificação de Solos. 3. ed. Brasília, DF: Embrapa, 2013. 353 p.

SILVA, M. A. S. et al. Efeito da aplicação de biochar sobre propriedades químicas do solo e produtividade de feijoeiro comum irrigado. In: CONGRESSO NACIONAL DE PESQUISA DE FEIJÃO, 10., 2011, Goiânia. Anais... Goiânia: Embrapa Arroz e Feijão, 2011. CD-ROM.
SOHI, S. P et al. A review of Biochar and its use and function in soil. Advances in Agronomy, San Diego, v. 105, s/n., p. 47-82, 2010.

SOMBROEK, W. G. et al. Amazonian Dark Earths as carbon stores and sinks. In.: LEHMANN, J. et al. (Eds.). Amazonian Dark Earths: origin, properties, and management. Dordrecht: Kluwer Academic Publishers, 2003. p. 125-139. Disponível em: $<$ http://link.springer.com/chapter/10.1007/14020-2597-1_7>. Acesso em: 29 jan. 2014.

STEINER, C. et al. Reducing nitrogen loss during poultry litter composting using biochar. Journal of Environmental Quality, Madison, v. 39, n. 4, p. 1236-1242, 2010.

STREUBEL, J. D. et al. Influence of contrasting biochar types on five soils at increasing rates of application. Soil Science Society of America Journal, Madison, v. 75, n. 4, p. 1402-1413, 2011.

VERHEIJEN, F. et al. Biochar Application to Soils. A Critical Scientific Review of Effects on Soil Properties, Processes and Functions. Ispra (Itália): European Commission, Joint Research Centre Institute for Environment and Sustainability, 2010. 166 p. Disponível em: <http:// eusoils.jrc.ec.europa.eu/esdb archive/eusoils docs/ other/ eur24099.pdf> Acesso em: 29 jan. 2014.

YOSEFTABAR, S. Effect of nitrogen management on panicle structure and yield in rice (Oryza sativa L.). International Journal of Agriculture and Crop Sciences, London, v. 5, n. 11, p. 1224-1227, 2013.

YOSHIDA, S. Fundamentals of rice crop science. Los Baños: IRRI, 1981. 269 p.

ZHANG, Y. J. et al. Effects of nitrogen nutrition on grain yield of upland and paddy rice under different cultivation methods. Acta Agronomica Sinica, Beijing, v. 34, n. 6, p. 1005-1013, 2008.

WANG, L. et al. Effect of crop residue biochar on soil acidity amelioration in strongly acidic tea garden soils. Soil Use and Management, Bedford, v. 30, n. 1, p. 119-128, 2014. 